British Association \section{Scientists to be} seen and heard

\section{Brighton}

EDITORS should give more prominence to scientists as people in their science features according to Professor John Maynard Smith of the University of Sussex, addressing a large audience at the annual meeting of the British Association. Scientists, for their part, should make a greater effort to be understood by the public, even at the cost of abandoning some of the qualifications they might ordinarily make to cover themselves.

While past generations learnt about science through the popular writings of active scientists, the young of today are more likely to become acquainted with science through a script written by a television producer or an article commissioned by a newspaper editor, he said. Although scientists cannot (and, indeed, should not) be the only interpreters of science to the public, there is a danger that editors may create controversy where none exists.

Maynard Smith claimed that some newspaper articles and television programmes had represented the gradualism versus punctuated equilibrium debate in evolution as though it were the last nail in the coffin of natural selection. The reality is that biologists are about as likely to abandon that theory as are chemists to abandon the atomic theory.

The blame for this sort of confusion usually lies with commissioning editors, who may have little understanding or affection for science, rather than with professional science writers. Some recent feature articles in the London Times had been commissioned from prominent scientists but their expertise lay in areas of science entirely different from that on which they were writing, said Maynard Smith, a biologist of distinction. "I can tell you that I have some doubts of my own about quantum physics. But I should hardly expect to be given a full page of a newspaper to write about them."

Although there are many excellent science programmes on television, the "voice-over" technique that is sometimes used denies scientists their identity as human beings. Professor Maynard Smith, whose face is well known to UK television audiences, drew an amusing caricature of many programmes: first of all the audience is treated to a shot of a white-coated junior scientist (probably a woman) pressing buttons on an incomprehensible machine, then a more senior scientist (probably a man, and probably not wearing a white coat) is shown sitting behind a desk getting very excited about something. Before he can explain himself an anonymous "voiceover" offers the producer's interpretation of what is going on.

Tim Beardsley

European Community \title{
Counting the cost of agriculture
}

\section{Brussels}

RUNAWAY farm spending is the most pressing problem facing the European Community when it returns from its annual vacation in September. Until the problem is solved, the Commission's ambitious plans for spending on technology and scientific research cannot progress.

Agricultural spending - which gobbles up more than two-thirds of the Community's annual budget of 25,000 million ECU (1 ECU $=£ 0.58)$ - has long been a point of contention, pitting countries with strong farm lobbies against those with weaker lobbies that are more disposed to change. What adds a touch of drama to the present situation is the fact that the predicted 30 per cent increase in farm expenditure this year will completely exhaust the Community's finances.

The failure of European farm policy and its system of open-ended production and export subsidies is illustrated by the present state of farm surpluses. After three years of almost empty warehouses, due mainly to high world market prices and sustained demand, stocks have again built up this year.

Output in the dairy sector, the largest single farm sector, accounting for 20 per cent of the Community's total farm expenditure, is expected to rise 3.5 per cent this year, while demand within the Community is stagnating and trade frictions with the United States on export markets have led to reduced demand elsewhere. At the end of July, the European butter mountain had reached a record 770,000 tonnes, while public stocks of milk powder amount to almost one million tonnes, more than twice those of a year ago.

Surpluses are not restricted to the dairy sector. This year's harvest is expected to push up wheat stocks to almost 11 million tonnes ( 5 million tonnes more than last year), while barley and rye stocks have increased dramatically to 812,000 and 306,000 tonnes respectively. Beef surpluses total more than 300,000 tonnes, up from 75,000 tonnes a year ago, and olive oil stocks, although smaller than last year, still exceed 122,000 tonnes.

Moreover, Commission officials fear that a record wine crop forecast for this year might lead to a crisis similar to last summer's "wine war", when French farmers destroyed low-cost imports from Italy and Spain, leading to an open political crisis between Italy and France.

European farm support mechanisms are increasingly complicated, but this does not prevent expenses from soaring and surplus stocks from getting out of control. "The way the Community settled the wine war is typical: no structural changes, merely cosmetics", one official noted. "To ease the tensions, it agreed to finance a largescale distillation operation involving 13.8 million hectolitres of cheap wine at a total cost of more than 400 million ECU. Then it had to subsidize the storage and marketing of the alcohol to avoid the collapse of the European alcohol market."

One possible solution is simple - in theory. Production would be curbed and guaranteed prices within the Community brought in line with world market prices. Farmers would shift from surplus production to shortage crops and, in general, there would be much more competition.

New proposals by the European Commission along these lines include output ceilings and penalty taxes on excess production, increased import duties on animal feeds, reduced aid to European beef and sheep breeders and a consumers' tax on vegetable fats. Most of these proposals have been made before and rejected by European governments. This year, they have again met violent criticism by European politicians and farm lobbies.

However, commission officials hope that the budgetary crisis now faced by the Community and the consensus to curb farm spending will increase the chances of the proposals being well received at the European summit in Athens in December. But there is little faith in Brussels that European governments are willing to make the necessary concessions and come to terms with a problem that has become a threat to the survival of the Community.

Geert Linnebank

\section{Texas thinking big}

\section{Washington}

TEXAS A\&M University, which, together with the University of Texas, has received much attention lately for its efforts to turn oil and gas revenues into prestige, has bagged its first Nobel Prize winner. The university announced earlier this month that $\mathrm{Dr}$ Norman Borlaug, who won the Nobel peace prize in 1970 for his development of high-yielding varieties of wheat that set off the "green revolution", will join the faculty next January.

University officials were unashamedly exuberant about their coup; Texas A\&M president Frank Vandiver called it "a major step forward in our quest for preeminence", and, added, in a very faint nod to institutional humility, "it is appropriate that our first Nobel Laureate should be in agriculture"'.

Borlaug will hold the position of "Distinguished Professor of International Agriculture" while continuing his association with the International Maize and Wheat Improvement Center in Mexico City. His salary at Texas A\&M, according to the press office there, will be equivalent to a full-time salary of $\$ 100,000$ per year.

Stephen Budiansky 